\title{
Effect of urban air pollution on CRP and coagulation: a study on inpatients with acute exacerbation of chronic obstructive pulmonary disease
}

Lingling Tang ${ }^{1,4 \dagger}$, Suofang Shi ${ }^{{ }^{*}{ }^{+}}$, Bohan Wang ${ }^{1 \dagger}, \mathrm{Li} \mathrm{Liu}^{3}$, Ying Yang ${ }^{1}$, Xianhong Sun ${ }^{1}$, Zhenhua $\mathrm{Ni}^{5}$ and Xiongbiao Wang ${ }^{4^{*}}$

\begin{abstract}
Purpose: Acute exacerbation of chronic obstructive pulmonary disease (AECOPD) is an important event in the course of chronic obstructive pulmonary disease that negatively affects patients' quality of life and leads to higher socioeconomic costs. While previous studies have demonstrated a significant association between urban air pollution and hospitalization for AECOPD, there is a lack of research on the impact of particulate matter (PM) on inflammation and coagulation in AECOPD inpatients. Therefore, this study investigated the association of changes in coagulation function and C-reactive protein (CRP) with PM levels in the days preceding hospitalization.
\end{abstract}

Patients and methods: We reviewed the medical records of AECOPD patients admitted to Putuo Hospital, Shanghai University of Traditional Chinese Medicine, between March 2017 and September 2019. We analyzed the association of coagulation function and CRP level in AECOPD patients with PM levels in the days before hospitalization. Multivariate unconditional logistic regression analyses were used to evaluate the adjusted odds ratio (OR) and 95\% confidence interval (CI) for the association of CRP data with hospitalization day. Kruskal-Wallis tests were used to evaluate mean aerodynamic diameter of $\geq 2.5 \mu \mathrm{m}\left(\mathrm{PM}_{2.5}\right)$ exposure on the day before hospitalization; we assessed its association with changes in prothrombin time (PT) in AECOPD inpatients with different Global Initiative for Chronic Obstructive Lung Disease (GOLD) classes.

Results: The peripheral blood PT of AECOPD patients with $\mathrm{PM}_{2.5} \geq 25 \mathrm{mg} / \mathrm{L}$ on the day before hospitalization were lower than those of patients with $\mathrm{PM}_{2.5}<25 \mathrm{mg} / \mathrm{L}(t=2.052, p=0.041)$. Patients with severe GOLD class exposed to greater than $25 \mathrm{mg} / \mathrm{L}$ of $\mathrm{PM}_{2.5}$ on the day before hospitalization showed significant differences in PT $(F=9.683$, $p=0.008$ ). Peripheral blood CRP levels of AECOPD patients exposed to $P_{2.5} \geq 25 \mathrm{mg} / \mathrm{L}$ and $P M_{10} \geq 50 \mathrm{mg} / \mathrm{L}$ on the day before hospitalization were higher than those of patients exposed to $P M_{2.5}<25 \mathrm{mg} / \mathrm{L}$ and $P M_{10}<50 \mathrm{mg} / \mathrm{L}$

*Correspondence: jsssf2006@126.com; xiongbiao6@yahoo.com

'Lingling Tang, Suofang Shi and Bohan Wang contributed equally to this

work

${ }^{2}$ Department of Respiratory Medicine, Affiliated Hospital of Nanjing

University of Chinese Medicine, Nanjing 210029, Jiangsu, China

${ }^{4}$ Department of Respiratory Medicine, Putuo Hospital, Shanghai

University of Traditional Chinese Medicine, Shanghai 200062, China

Full list of author information is available at the end of the article

(C) The Author(s) 2021. Open Access This article is licensed under a Creative Commons Attribution 4.0 International License, which permits use, sharing, adaptation, distribution and reproduction in any medium or format, as long as you give appropriate credit to the original author(s) and the source, provide a link to the Creative Commons licence, and indicate if changes were made. The images or other third party material in this article are included in the article's Creative Commons licence, unless indicated otherwise in a credit line to the material. If material is not included in the article's Creative Commons licence and your intended use is not permitted by statutory regulation or exceeds the permitted use, you will need to obtain permission directly from the copyright holder. To view a copy of this licence, visit http://creativecommons.org/licenses/by/4.0/. The Creative Commons Public Domain Dedication waiver (http://creativeco mmons.org/publicdomain/zero/1.0/) applies to the data made available in this article, unless otherwise stated in a credit line to the data. 
( $t=2.008, p=0.046 ; t=2.637, p=0.009$ ). Exposure to $<25 \mathrm{mg} / \mathrm{L}$ of $\mathrm{PM}_{2.5}$ on the day before hospitalization was significantly associated with CRP levels (adjusted OR 1.91; $95 \% \mathrm{Cl} 1.101,3.315 ; p=0.024$ ).

Conclusion: Exposure of patients with AECOPD to high PM levels on the day before hospitalization was associated with an increased CRP level and shortened PT. Moreover, PM $_{2.5}$ had a greater effect on CRP level and PT than mean aerodynamic diameter of $\geq 10 \mu \mathrm{m}\left(\mathrm{PM}_{10}\right)$. AECOPD patients with severe GOLD class were more sensitive to $\mathrm{PM}_{2.5}$-induced shortening of PT than those with other GOLD classes.

Keywords: Acute exacerbation of chronic obstructive pulmonary disease, Ambient air quality, Particulate matter, Coagulation, Inflammation

\section{Introduction}

Chronic obstructive pulmonary disease (COPD) is considered a heterogeneous syndrome and has been associated with abnormal inflammatory immune responses in the lungs to particulate air pollution [1]. Exposure to ambient PM increases the incidence of AECOPD events, and a higher median of fine $\mathrm{PM}_{2.5}$ at $48 \mathrm{~h}$ before the onset of symptoms has been reported [2, 3]. PM exposure leads to AECOPD mediated via oxidative stress, airway inflammation, altered airway epithelial structure, and immune dysfunction [4]. Li et al. reported an association between air pollution and COPD mortality through distributed lag non-linear models, with an increase in PM level by $10 \mu \mathrm{g} / \mathrm{m}^{3}$ resulting in a $1.58 \%$ increase in COPD mortality over a lag of $0-15$ days [5]. It is estimated that the burden of death caused by air pollution is annually as high as 40,000 people in the UK. By 2035 , health and social care expenses caused by air pollution will reach a maximum of $£ 18.6$ billion [6]. With the aging of world's population and rapid urbanization, the burden of COPD will increase in the next years. Therefore, from the perspective of public health and policy, as well as in the context of disease and environmental pollution prevention, it is crucial to understand how the pathophysiologic mechanisms induced by ambient air pollutants might induce adverse AECOPD.

Coagulation markers are potential predictors of COPD exacerbations and increased mortality, and the coagulation cascade has bene identified as a potential therapeutic target in COPD [7]. Plasma D-dimer level and blood coagulation indicators are used to monitoring the efficacy of low-molecular-weight heparin calcium therapy to improve blood coagulation and pulmonary functions in COPD patients [8]. An association has also been observed between long-term exposure to PM and level of coagulation [9]. Liu et al. reported robust associations between the constituents of $\mathrm{PM}_{2.5}$ (sulfate and ammonium) and coagulation markers, with an interquartile range increase in the two parameters corresponding to increments of $23 \%$ and $20 \%$ in plasminogen activator inhibitor-1 and soluble CD40 ligand levels, respectively [10]. While previous studies have demonstrated a significant association of urban air pollution with inflammation and coagulation, there is a paucity of research on the impact of particulate matter (PM) on inflammation and coagulation in AECOPD inpatients.

Shanghai is one of the most polluted cities in China, with $\mathrm{PM}_{10}$ and $\mathrm{PM}_{2.5}$ being the main pollutants [11]. For several years, air pollution has been a severe problem in Shanghai, reaching values higher than the recommendations of the World Health Organization (WHO) guidelines [12]. For instance, from March 2017 to September 2019, the mean $\mathrm{PM}_{2.5}$ and $\mathrm{PM}_{10}$ concentrations were 35 and $58 \mu \mathrm{g} / \mathrm{m}^{3}$, with maximum 24-h values of 189 and $255 \mu \mathrm{g} / \mathrm{m}^{3}$, respectively. An epidemiological survey in Shanghai reported that particles $<0.5 \mu \mathrm{m}$ in diameter might be responsible for the adverse effects of particulate air pollution on COPD mortality [13]. Thus, there is an urgent need to investigate and understand the relationship between exposure to air pollution and the pathogenesis of AECOPD. This cohort study investigated the association between changes in coagulation function and level of the inflammatory biomarker-CRP-with $\mathrm{PM}_{2.5}$ and $\mathrm{PM}_{10}$ exposure levels in the days before hospitalization due to AECOPD. We hypothesized that PM exposure aggravates the diseases of the respiratory system associated with inflammation by inducing vascular endothelial injury and pro-coagulation.

\section{Materials and methods Study population}

We retrospectively analyzed the medical records of 446 patients with AECOPD who were admitted to the Putuo Hospital Affiliated to Shanghai University of Traditional Chinese Medicine (Shanghai, China) from March 2017 to September 2019. The inclusion criteria were as follows: classification of patients with COPD according to the Global Initiative for Chronic Obstructive Lung Disease (GOLD) guidelines and acute exacerbation, defined as suddenly worsening of clinical respiratory symptomsespecially dyspnea, cough, and purulent sputum-resulting in the need for treatment measures in addition to the existing treatment regimen [14]. The data collected included the main characteristics of patients with a 
complete medical history. Clinical data were collected after hospitalization. Data related to $\mathrm{C}$-reactive protein (CRP) concentration, D-dimer level, thrombin time (TT), prothrombin time (PT), fibrinogen (FIB) concentration, activated partial thromboplastin time (APTT), medical and medication history, smoking and exposure to PM, body mass index (BMI), and comorbidities (coronary heart disease, hypertension, asthma, bronchiectasis, and diabetes) were collected. The exclusion criteria were as follows: patients who suffered from thromboembolic disease, taking blood-thinning drugs (e.g., warfarin or antiplatelet drugs) or steroids, or place of residence and work to be out of Putuo district (Shanghai, China) within 7 days before the onset of symptoms.

The severity level of the acute exacerbations in patients with COPD was determined according to the 2016 GOLD classification [14]. In adults, serum CRP level $\geq 10 \mathrm{mg} / \mathrm{L}$ is generally considered to be a significant marker of inflammation caused by an infectious or noninfectious cause [15]. Patients with concurrent use of statins, inhaled corticosteroids and blood-thinning drugs were defined as those whose last use of statins, inhaled corticosteroids and blood-thinning drugs was $\leq 7$ days before the date of AECOPD diagnosis or those still taking these drugs on the day of AECOPD diagnosis. Passive smoking was defined as being in the same room with a smoker for at least an hour/day for 12 or more consecutive months [16].

\section{Air pollution and climate data}

The hourly concentrations of air pollutants in Putuo district were provided by the State Environmental Protection Administration of China (Monitoring Station $\# 1141 \mathrm{~A}$ ), and the average 24-h $\mathrm{PM}_{2.5}$ and $\mathrm{PM}_{10}$ values were calculated. According to World Health Organization recommendations, daily average $\mathrm{PM}_{2.5}$ exposure level $>25 \mu \mathrm{g} / \mathrm{m}^{3}$ and $\mathrm{PM}_{10}$ exposure level $>50 \mu \mathrm{g} / \mathrm{m}^{3}$ were defined as above average daily exposure levels [12].

\section{Statistical analysis}

Data were statistically analyzed using IBM SPSS Statistics for Windows, version 21.0. (IBM Corp., Armonk, NY, USA). All reported $p$-values were two-sided. Pearson's correlation analysis was used to assess the relationships between $\mathrm{PM}_{2.5} / \mathrm{PM}_{10}$ and the level of coagulation/ inflammatory factors. Student's $t$-tests were used to assess the differences in CRP and markers of coagulation between PM exposure levels higher and lower than the average daily exposure levels. Multivariate unconditional logistic regression analyses were used to evaluate the adjusted odds ratio (OR) and 95\% confidence interval (CI) for the association of CRP level with PM exposure level before the hospitalization day. Variables were statistically significant in the multivariate logistic regression model. The adjusted GOLD classes included history of smoking, hypertension, coronary heart disease, and $\mathrm{PM}_{2.5}$ and $\mathrm{PM}_{10}$ exposure levels. The Kruskal-Wallis test or the Student's $t$-test were used to evaluate the associations between $\mathrm{PM}_{2.5}$ exposure levels on the day before hospitalization and changes in PT in AECOPD patients in different demographic and clinical features, such as GOLD classes, age, gender, BMI, history of smoking, use of statins, administration of inhaled corticosteroids, and incidence of comorbidities. $p$-values $<0.05$ were considered statistically significant for single comparisons.

\section{Ethics approval and consent to participate}

The study protocol was approved by the institutional review board of Putuo Hospital, Shanghai University of Traditional Chinese Medicine (approval number: PTECA-2018-25-1). The study was conducted in accordance with the principles of the Declaration of Helsinki.

\section{Results}

In this study, data of 446 AECOPD patients, who were hospitalized at Putuo Hospital Affiliated to Shanghai University of Traditional Chinese Medicine between March 2017 and September 2019, were collected from medical record system and were retrospectively analyzed. Among them, 81 patients were excluded due to suffering from thromboembolic disease, taking blood-thinning drugs or steroids, or place of residence and work to be out of Putuo district within 7 days before the onset of symptoms. Finally, this study included 317 patients with AECOPD (Fig. 1). The basic demographic information of the enrolled patients (age, sex, GOLD class, inhaled corticosteroid use, smoking status, passive smoking status, statin use, inhaled corticosteroid use, and comorbidities) is shown in Table 1. The data of $\mathrm{PM}_{2.5} / \mathrm{PM}_{10}$ and meteorological factors in the days preceding hospitalization period are summarized in Table 2.

\section{Relationship between coagulation function in patients with AECOPD and PM level in the days before hospitalization}

As shown in Table 3, the results of Pearson's correlation analysis revealed that there were no significant relationships between $\mathrm{PM}_{2.5} / \mathrm{PM}_{10}$ and the levels of coagulation/ inflammatory factors. When $25 \mathrm{mg} / \mathrm{L}$ was used as cutting point, no significant differences were also observed between the levels of coagulation function indicators (D-dimer level, TT, PT, FIB level, and APTT) in patients with AECOPD and the PM levels on the day and two days before hospitalization. However, the mean PT in patients with AECOPD who were subjected to $\mathrm{PM}_{2.5}$ level $\geq 25 \mathrm{mg} / \mathrm{L}$ on the day before hospitalization was 


\section{Inclusion criteria:}

Main diagnosis (The data collected included the main characteristicsof AECOPD patients with a complete medical history $(\mathrm{n}=446))$

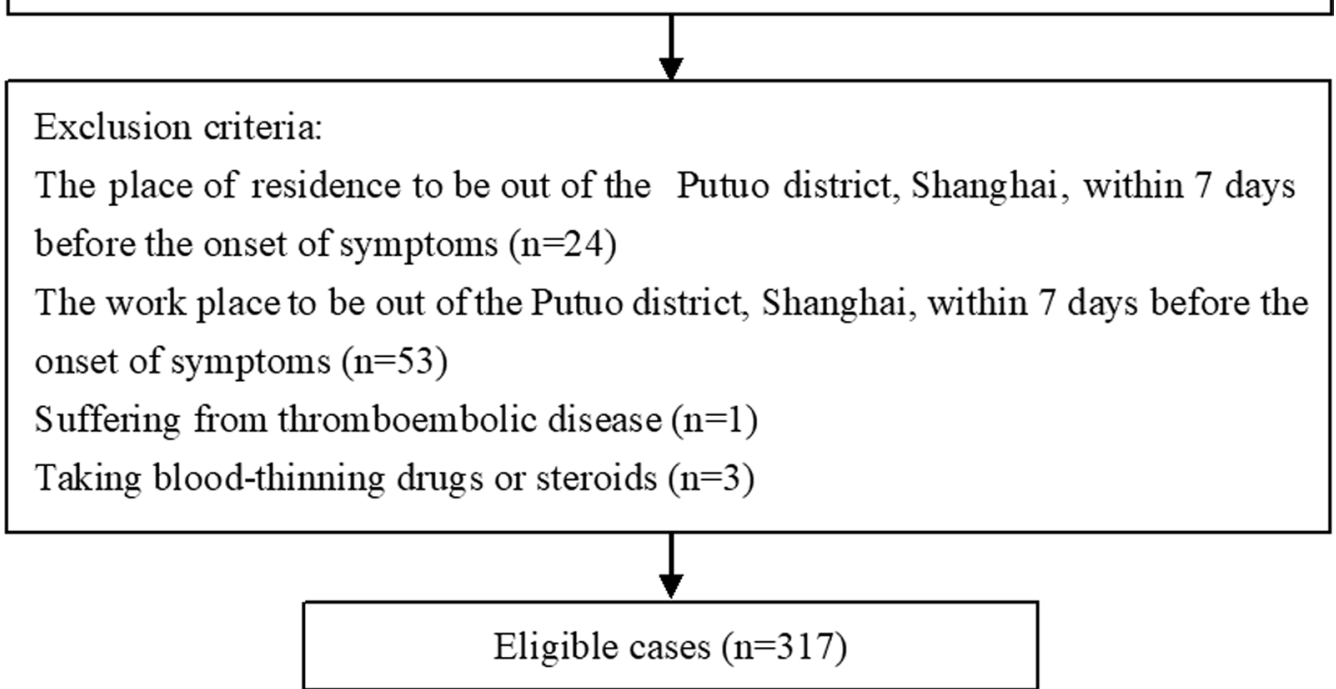

Fig. 1 Flowchart of patients' selection

$12.03 \pm 1.89 \mathrm{~s}$, which was markedly higher than that in patients subjected to $\mathrm{PM}_{2.5}$ level $<25 \mathrm{mg} / \mathrm{L}(t=2.052$, $p=0.041)$. The mean PT in patients with AECOPD who were subjected to $\mathrm{PM}_{10}$ level $\geq 50 \mathrm{mg} / \mathrm{L}$ on the day before hospitalization was $0.28 \mathrm{~s}$, which was longer than that in patients exposed to $\mathrm{PM}_{10}$ level $<50 \mathrm{mg} / \mathrm{L}$; however, the difference was not statistically significant (Tables 4,5 ).

\section{$\mathrm{PM}_{2.5}$ exposure level on the day before hospitalization was associated with changes in $\mathrm{PT}$ in patients with AECOPD with different GOLD classes}

In this study present some evidence to indicate that the hypercoagulable state was affected by PM exposure in patients with AECOPD with different COPD severities (different GOLD classes). AECOPD patients with different GOLD classes exposed to $\mathrm{PM}_{2.5}$ levels $<25 \mathrm{mg} / \mathrm{L}$ on the day before hospitalization showed no significant difference in average PT. However, patients with AECOPD exposed to $\mathrm{PM}_{2.5}$ levels $\geq 25 \mathrm{mg} / \mathrm{L}$ on the day before hospitalization showed significant differences in PT according to disease severities; this is particularly true for patients with more serious AECOPD $(F=9.683$, $p=0.008$ ). There was no significant difference between PM2.5 level on the day before hospitalization and changes in PT in AECOPD patients with other different demographic and clinical features (Table 6).
Relationship between CRP concentration in patients with AECOPD and PM exposure levels in the days before hospitalization

Similar to the changes in coagulation function indicators, patients with AECOPD showed no significant difference between peripheral blood CRP concentration and PM exposure levels on the day of and two days before hospitalization. The mean peripheral blood CRP level of patients with AECOPD exposed to $\mathrm{PM}_{2.5}$ levels $\geq 25 \mathrm{mg} / \mathrm{L}$ on the day before hospitalization was $11.3 \mathrm{mg} / \mathrm{L}$ - an average of $3.03 \mathrm{mg} / \mathrm{L}$ higher than that in patients exposed to $\mathrm{PM}_{2.5}$ levels $<25 \mathrm{mg} / \mathrm{L}(t=2.008$, $p=0.046)$. The mean peripheral blood CRP level of patients with AECOPD exposed to $\mathrm{PM}_{10}$ levels $\geq 50 \mathrm{mg} / \mathrm{L}$ on the day before hospitalization was $12.41 \mathrm{mg} / \mathrm{L}$-an average of $3.75 \mathrm{mg} / \mathrm{L}$ higher than that in patients exposed to $\mathrm{PM}_{10}$ levels $<50 \mathrm{mg} / \mathrm{L}(t=2.637, p=0.009)$ (Tables 4 , 5).

\section{Risk of increased CRP level and its association with PM exposure level on the day before hospitalization, comorbidities, BMI, smoking, and drug use}

Multivariate logistic regression analysis revealed that patients with AECOPD exposed to higher $\mathrm{PM}_{2.5}$ levels on the day before hospitalization $\left(\mathrm{PM}_{2.5} \geq 25 \mathrm{mg} / \mathrm{L}\right)$ had 2.19-fold higher odds of having $C R P \geq 10 \mathrm{mg} / \mathrm{L}$ when 
Table 1 Patients' demographic and clinical characteristics

\begin{tabular}{|c|c|}
\hline Variable & Description \\
\hline \multicolumn{2}{|l|}{ Age years } \\
\hline$<65$ & $91(28.71 \%)$ \\
\hline$\geq 65$ & $226(71.29 \%)$ \\
\hline \multicolumn{2}{|l|}{ Sex } \\
\hline Female & 64 (20.19\%) \\
\hline Male & $253(79.81 \%)$ \\
\hline \multicolumn{2}{|l|}{ BMI $\left(\mathrm{kg} / \mathrm{m}^{2}\right)$} \\
\hline$<18.5$ & 31 (9.78\%) \\
\hline$\geq 18.5$ & $286(90.22 \%)$ \\
\hline \multicolumn{2}{|l|}{ GOLD classes } \\
\hline Moderate & 31 (9.78\%) \\
\hline Severe & $196(61.83 \%)$ \\
\hline Very severe & $90(28.39 \%)$ \\
\hline \multicolumn{2}{|l|}{ Current smoker } \\
\hline Yes & $42(13.25 \%)$ \\
\hline No & $275(86.75 \%)$ \\
\hline \multicolumn{2}{|l|}{ Passive smoking } \\
\hline Yes & $107(33.75 \%)$ \\
\hline No & $210(66.25 \%)$ \\
\hline \multicolumn{2}{|l|}{ Use of statins } \\
\hline Yes & $58(18.30 \%)$ \\
\hline No & $259(81.7 \%)$ \\
\hline \multicolumn{2}{|l|}{ Inhaled corticosteroids } \\
\hline Yes & $272(85.8 \%)$ \\
\hline No & 45 (14.2\%) \\
\hline \multicolumn{2}{|l|}{ Comorbidities } \\
\hline Hypertension & $116(36.59 \%)$ \\
\hline Coronary heart disease & 79 (24.92\%) \\
\hline Diabetes & $46(14.51 \%)$ \\
\hline Asthma & $27(8.51 \%)$ \\
\hline Bronchiectasis & $7(2.21 \%)$ \\
\hline
\end{tabular}

BMI, Body mass index; GOLD, Global Initiative for Chronic Obstructive Lung Disease

compared with those exposed to $\mathrm{PM}_{2.5}$ levels $<25 \mathrm{mg} / \mathrm{L}$ (95\% CI 1.283-3.747) and $\mathrm{PM}_{10}<50 \mathrm{mg} / \mathrm{L}$ (crude OR 1.86; 95\% CI 1.170, 2.948). After adjusting for GOLD classes, the smoking status, hypertension, coronary heart disease, $\mathrm{PM}_{2.5}$, and $\mathrm{PM}_{10}$, it was found that patients with AECOPD exposed to higher $\mathrm{PM}_{2.5}$ levels on the day before hospitalization $\left(\mathrm{PM}_{2.5} \geq 25 \mathrm{mg} / \mathrm{L}\right)$ had 1.19-fold higher odds of having CRP $>10 \mathrm{mg} / \mathrm{L}$ when compared to those exposed to $\mathrm{PM}_{2.5}<25 \mathrm{mg} / \mathrm{L}$ on the day before hospitalization (95\% CI 1.101, 3.315), indicating a significant association of high $\mathrm{PM}_{2.5}$ exposure level with CRP level $(p=0.024)$. However, the adjusted OR for the risk of increased CRP and high $\mathrm{PM}_{10}$ exposure on the day before hospitalization was not statistically significant. GOLD class (adjusted OR 1.5; 95\% CI
1.002-2.236), a current smoking status (adjusted OR 2.1; 95\% CI 1.109-4.361), and hypertension (adjusted OR 1.65 ; 95\% CI 1.019-2.683) were also significantly associated with CRP level (Table 7).

\section{Discussion}

Air pollution is a serious worldwide problem due to its impact on the human respiratory system. Morantes et al. [3] and Wang et al. [17] have reported the association between air pollution and increased incidence of AECOPD, and the relationship between air pollution and acute respiratory inflammation has been confirmed previously [18]. Gao et al. reported that exposure to air pollutants was associated with reduced predicted forced vital capacity (FVC\%pred) and increased systemic inflammation in patients with COPD, which may be attributed to changes in the proportions of CD4(+) T-cell subsets [19]. Patients with COPD are more susceptible to air pollution-associated respiratory inflammation than individuals without COPD [20]. Black carbon, a marker of exposure to traffic-based PM, has shown exposure-response relationships with biomarkers of systemic inflammation and endothelial activation in patients with COPD [21].

Increased morbidity and mortality from PM is hypothesized to be caused partly by systemic inflammation and a hypercoagulable state following pulmonary oxidative stress and inflammation [22]. However, previously reported associations for airborne particles with inflammation and hypercoagulability are highly heterogeneous. A cross-sectional study conducted by Sara et al. showed that, after adjusting for demographic, socioeconomic, behavioral, and health factors, there were limited evidences for relationships between markers of inflammation and $\mathrm{PM}_{10 / 2.5}$ or its components [23]. Another study reported that PM exposure was not accompanied with any short-term effects on PT, endogenous thrombin potential (ETP), and CRP within one week [4]. Research on the correlation among PM exposure, inflammation, and coagulation needs to eliminate a greater number of confounding factors and to consider a larger sample size, however, it is difficult to ensure that the time and concentration of exposure to PM can be unified with a larger sample size. Therefore, we are more inclined to perform research based on a small sample size and highly eliminate confounding factors. A retrospective study reported that $\mathrm{PM}_{2.5}$ level higher than $25 \mathrm{mg} / \mathrm{L}$ was associated with the increased purulent sputum, pleuritic chest pain, and the use of antibiotic and corticosteroid drugs [5]. We believe that PM2.5 level greater than $25 \mathrm{mg} / \mathrm{L}$ is an important cutting point for the accumulation of clinical symptoms in AECOPD patients. 
Table 2 Description of $\mathrm{PM}_{2.5} / \mathrm{PM}_{10}$ and meteorological factors on the days before hospitalization

\begin{tabular}{|c|c|c|c|c|c|c|}
\hline Variable & Max & 75th & Med & 25th & Min & Mean \pm SD \\
\hline \multicolumn{7}{|l|}{ The day of consultation } \\
\hline $\mathrm{PM}_{2.5}\left(\mu \mathrm{g} / \mathrm{m}^{3}\right)$ & 151.00 & 71.00 & 47.00 & 29.00 & 8.00 & $51.56 \pm 27.89$ \\
\hline $\mathrm{PM}_{10}\left(\mu \mathrm{g} / \mathrm{m}^{3}\right)$ & 144.00 & 76.00 & 56.00 & 38.00 & 5.00 & $58.58 \pm 26.37$ \\
\hline Temperature $\left({ }^{\circ} \mathrm{C}\right)$ & 34.80 & 27.20 & 17.05 & 8.80 & 1.70 & $18.18 \pm 9.91$ \\
\hline Relative humidity (\%) & 95.00 & 80.00 & 70.00 & 62.00 & 28.00 & $70.85 \pm 12.77$ \\
\hline \multicolumn{7}{|c|}{ The day before consultation } \\
\hline $\mathrm{PM}_{2.5}\left(\mu \mathrm{g} / \mathrm{m}^{3}\right)$ & 180.00 & 68.00 & 43.00 & 28.00 & 7.00 & $52.32 \pm 32.93$ \\
\hline $\mathrm{PM}_{10}\left(\mu \mathrm{g} / \mathrm{m}^{3}\right)$ & 171.00 & 77.00 & 53.00 & 35.00 & 6.00 & $58.36 \pm 29.36$ \\
\hline Temperature $\left({ }^{\circ} \mathrm{C}\right)$ & 33.90 & 26.70 & 18.10 & 10.10 & -1.00 & $17.78 \pm 8.87$ \\
\hline Relative humidity (\%) & 98.00 & 81.00 & 73.00 & 64.00 & 28.00 & $71.97 \pm 12.92$ \\
\hline \multicolumn{7}{|c|}{ Two day before consultation } \\
\hline $\mathrm{PM}_{2.5}\left(\mu \mathrm{g} / \mathrm{m}^{3}\right)$ & 183.00 & 74.00 & 39.00 & 25.00 & 6.00 & $52.05 \pm 39.78$ \\
\hline $\mathrm{PM}_{10}\left(\mu \mathrm{g} / \mathrm{m}^{3}\right)$ & 185.00 & 73.00 & 49.00 & 34.00 & 6.00 & $58.56 \pm 35.09$ \\
\hline Temperature $\left({ }^{\circ} \mathrm{C}\right)$ & 31.40 & 23.83 & 18.55 & 9.30 & 2.70 & $16.93 \pm 8.14$ \\
\hline Relative humidity (\%) & 95.00 & 79.00 & 70.00 & 62.00 & 38.00 & $70.80 \pm 12.27$ \\
\hline
\end{tabular}

CRP, C-reactive protein; $\mathrm{PM}_{2.5}$, Particulate matter smaller than $2.5 \mu \mathrm{m}$ in diameter; $\mathrm{PM}_{10}$, Particulate matter smaller than $10 \mu \mathrm{m}$ in diameter

Table 3 Correlation between concentrations of $\mathrm{PM}_{2.5} / \mathrm{PM}_{10}$ with coagulation function and CRP

\begin{tabular}{|c|c|c|c|c|c|c|c|c|c|c|c|c|}
\hline \multirow[t]{3}{*}{ Variable } & \multicolumn{4}{|c|}{ The day of hospitalization } & \multicolumn{4}{|c|}{ The day before hospitalization } & \multicolumn{4}{|c|}{ Two day before hospitalization } \\
\hline & \multicolumn{2}{|l|}{$\mathrm{PM}_{2.5}$} & \multicolumn{2}{|l|}{$\mathrm{PM}_{10}$} & \multicolumn{2}{|l|}{$\mathrm{PM}_{2.5}$} & \multicolumn{2}{|l|}{$\mathrm{PM}_{10}$} & \multicolumn{2}{|l|}{$\mathrm{PM}_{2.5}$} & \multicolumn{2}{|l|}{$\mathrm{PM}_{10}$} \\
\hline & $R$ & $p$ & $r$ & $p$ & $r$ & $p$ & $r$ & $p$ & $r$ & $p$ & $r$ & $p$ \\
\hline D dimer & -0.027 & 0.627 & 0.004 & 0.943 & 0.016 & 0.775 & 0.043 & 0.453 & 0.010 & 0.855 & 0.033 & 0.557 \\
\hline TT & -0.077 & 0.173 & -0.014 & 0.412 & -0.094 & 0.098 & -0.058 & 0.301 & -0.097 & 0.087 & 0.018 & 0.703 \\
\hline PT & -0.010 & 0.860 & -0.026 & 0.639 & -0.106 & 0.060 & -0.096 & 0.092 & -0.005 & 0.932 & -0.082 & 0.150 \\
\hline $\mathrm{FIB}$ & 0.010 & 0.858 & 0.003 & 0.985 & 0.054 & 0.341 & 0.023 & 0.832 & 0.045 & 0.424 & 0.032 & 0.572 \\
\hline APTT & 0.047 & 0.404 & 0.066 & 0.251 & -0.001 & 0.987 & -0.047 & 0.409 & 0.014 & 0.804 & 0.005 & 0.953 \\
\hline CRP & 0.050 & 0.405 & 0.078 & 0.184 & 0.068 & 0.248 & 0.083 & 0.162 & 0.011 & 0.855 & 0.047 & 0.428 \\
\hline
\end{tabular}

$\mathrm{PM}_{2.5}$, Particulate matter smaller than $2.5 \mu \mathrm{m}$ in diameter; $\mathrm{PM}_{10}$, Particulate matter smaller than $10 \mu \mathrm{m}$ in diameter; $\mathrm{TT}$, Thrombin Time; PT, Prothrombin Time; FIB, Fibrinogen; APTT, Activated Partial Thromboplastin Time; CRP, C-reactive protein

$p$-values are shown for the Pearson's correlation analysis

Table 4 Estimated changes in coagulation function and CRP in AECOPD patients associated with PM $_{10}$

\begin{tabular}{|c|c|c|c|c|c|c|c|c|c|c|c|c|}
\hline \multirow[t]{3}{*}{ Variable } & \multicolumn{12}{|l|}{$\mathrm{PM}_{10}$} \\
\hline & \multicolumn{4}{|c|}{ The day of hospitalization } & \multicolumn{4}{|c|}{ The day before hospitalization } & \multicolumn{4}{|c|}{ Two day before hospitalization } \\
\hline & $\begin{array}{l}<50 \mathrm{mg} / \mathrm{L} \\
\mathrm{n}=158\end{array}$ & $\begin{array}{l}\geq 50 \mathrm{mg} / \mathrm{L} \\
\mathrm{n}=159\end{array}$ & $t$ & $p$ & $\begin{array}{l}<50 \mathrm{mg} / \mathrm{L} \\
\mathrm{n}=142\end{array}$ & $\begin{array}{l}\geq 50 \mathrm{mg} / \mathrm{L} \\
\mathrm{n}=175\end{array}$ & $t$ & $p$ & $\begin{array}{l}<50 \mathrm{mg} / \mathrm{L} \\
\mathrm{n}=133\end{array}$ & $\begin{array}{l}\geq 50 \mathrm{mg} / \mathrm{L} \\
\mathrm{n}=184\end{array}$ & $t$ & $p$ \\
\hline D dimer & $0.69 \pm 0.92$ & $0.75 \pm 1.17$ & 0.524 & 0.601 & $0.68 \pm 0.92$ & $0.75 \pm 1.13$ & 0.608 & 0.544 & $0.73 \pm 1.12$ & $0.68 \pm 0.87$ & 0.430 & 0.667 \\
\hline $\mathrm{TT}$ & $15.99 \pm 3.63$ & $16.41 \pm 1.52$ & 1.662 & 0.098 & $16.34 \pm 2.13$ & $16.04 \pm 3.45$ & 0.949 & 0.343 & $16.38 \pm 2.72$ & $15.95 \pm 2.89$ & 1.737 & 0.083 \\
\hline PT & $12.33 \pm 2.35$ & $12.31 \pm 1.73$ & 0.125 & 0.900 & $12.48 \pm 1.60$ & $12.20 \pm 2.48$ & 1.163 & 0.242 & $12.36 \pm 1.85$ & $12.30 \pm 2.32$ & 0.272 & 0.786 \\
\hline $\mathrm{FIB}$ & $4.05 \pm 2.92$ & $3.73 \pm 1.39$ & 1.275 & 0.203 & $4.25 \pm 4.01$ & $4.53 \pm 4.30$ & 0.599 & 0.550 & $4.21 \pm 3.88$ & $4.60 \pm 4.47$ & 0.821 & 0.412 \\
\hline APTT & $27.94 \pm 4.58$ & $28.81 \pm 3.96$ & 1.815 & 0.070 & $28.61 \pm 4.72$ & $28.01 \pm 4.05$ & 1.218 & 0.224 & $28.55 \pm 4.12$ & $28.09 \pm 4.53$ & 0.922 & 0.357 \\
\hline CRP & $10.17 \pm 12.36$ & $10.73 \pm 11.87$ & 0.411 & 0.681 & $8.84 \pm 11.54$ & $12.41 \pm 12.52$ & 2.637 & 0.009 & $9.86 \pm 12.46$ & $11.26 \pm 11.58$ & 1.017 & 0.310 \\
\hline
\end{tabular}

$\mathrm{PM}_{10}$, Particulate matter smaller than $10 \mu \mathrm{m}$ in diameter; TT, Thrombin Time; PT, Prothrombin Time; FIB, Fibrinogen; APTT, Activated Partial Thromboplastin Time; $\mathrm{CRP}, \mathrm{C}$-reactive protein

$p$-values are shown for the Student's t-tests 
Table 5 Estimated changes in coagulation function and CRP in AECOPD patients associated with PM $_{2.5}$

\begin{tabular}{|c|c|c|c|c|c|c|c|c|c|c|c|c|}
\hline \multirow[t]{3}{*}{ Variable } & \multicolumn{12}{|l|}{$\mathrm{PM}_{2.5}$} \\
\hline & \multicolumn{4}{|c|}{ The day of hospitalization } & \multicolumn{4}{|c|}{ The day before hospitalization } & \multicolumn{4}{|c|}{ Two day before hospitalization } \\
\hline & $\begin{array}{l}<25 \mathrm{mg} / \mathrm{L} \\
\mathrm{n}=228\end{array}$ & $\begin{array}{l}\geq 25 \mathrm{mg} / \mathrm{L} \\
\mathrm{n}=\mathbf{8 9}\end{array}$ & $t$ & $p$ & $\begin{array}{l}<25 \mathrm{mg} / \mathrm{L} \\
\mathrm{n}=228\end{array}$ & $\begin{array}{l}\geq 25 \mathrm{mg} / \mathrm{L} \\
\mathrm{n}=89\end{array}$ & $t$ & $p$ & $\begin{array}{l}<25 \mathrm{mg} / \mathrm{L} \\
\mathrm{n}=220\end{array}$ & $\begin{array}{l}\geq 25 \mathrm{mg} / \mathrm{L} \\
\mathrm{n}=97\end{array}$ & $t$ & $p$ \\
\hline D dimer & $0.75 \pm 1.06$ & $0.70 \pm 1.01$ & 0.384 & 0.702 & $0.68 \pm 1.01$ & $0.73 \pm 1.03$ & 0.690 & 0.399 & $0.69 \pm 0.89$ & $0.72 \pm 1.08$ & 0.249 & 0.804 \\
\hline $\mathrm{TT}$ & $16.39 \pm 3.47$ & $16.13 \pm 2.49$ & 0.763 & 0.446 & $16.39 \pm 2.39$ & $16.13 \pm 2.94$ & 0.731 & 0.465 & $16.31 \pm 2.24$ & $16.16 \pm 3.02$ & 0.433 & 0.665 \\
\hline PT & $12.41 \pm 2.29$ & $12.29 \pm 2.07$ & 0.450 & 0.653 & $12.61 \pm 2.76$ & $12.03 \pm 1.89$ & 2.052 & 0.041 & $12.42 \pm 2.59$ & $12.28 \pm 1.90$ & 0.550 & 0.583 \\
\hline $\mathrm{FIB}$ & $4.33 \pm 3.20$ & $4.39 \pm 4.45$ & 0.110 & 0.912 & $4.55 \pm 4.85$ & $4.31 \pm 3.83$ & 0.466 & 0.642 & $4.29 \pm 4.60$ & $4.41 \pm 3.93$ & 0.246 & 0.806 \\
\hline APTT & $27.97 \pm 4.44$ & $28.40 \pm 4.35$ & 0.770 & 0.442 & $28.13 \pm 4.27$ & $28.34 \pm 4.42$ & 0.703 & 0.382 & $28.36 \pm 4.48$ & $28.24 \pm 4.32$ & 0.229 & 0.819 \\
\hline CRP & $10.52 \pm 11.94$ & $10.42 \pm 12.19$ & 0.066 & 0.947 & $8.27 \pm 11.84$ & $11.30 \pm 12.13$ & 2.008 & 0.046 & $9.33 \pm 12.21$ & $10.89 \pm 12.02$ & 1.060 & 0.290 \\
\hline
\end{tabular}

$\mathrm{PM}_{2.5}$, Particulate matter smaller than $2.5 \mu \mathrm{m}$ in diameter; TT, Thrombin Time; PT, Prothrombin Time; FIB, Fibrinogen; APTT, Activated Partial Thromboplastin Time; CRP,C-reactive protein

$p$-values are shown for the Student's t-tests

Systemic biomarkers of inflammation include high blood CRP levels in cases of COPD exacerbations [24]; moreover, CRP is a predictor of COPD hospitalization and death [25]. Garshick et al. reported a positive relationship between black carbon exposure level and CRP concentration, with the largest effect size observed for black carbon levels averaged over the previous 7 days [21]. This finding reflected the hysteresis of CRP to air pollution. A meta-analysis showed that long-term exposure to particulate air pollution was more strongly associated with CRP level than short-term exposure [26]; however, CRP concentration in patients with COPD on the day of hospitalization was associated with significantly increased PM levels on the day before hospitalization, suggesting that CRP level in patients with COPD is sensitive to short-term $\mathrm{PM}_{2.5}$ exposure.

Even exposure to ambient PM may induce a systemic inflammatory response; however, its reported associations with CRP levels are inconsistent [26, 27]. Li et al. found no consistent relationship between PM exposure and CRP levels in adults with chronic inflammatory conditions [28]. The use of anti-inflammatory drugs may explain this reduced association. As an indicator of systemic inflammation, CRP is a marker for functional capacity and distress due to respiratory symptoms in COPD; moreover, COPD patients with very severe GOLD stage reportedly has higher CRP levels than those belonging to the other stages [29]. Statin use was associated with a reduced risk of COPD exacerbation, and statins have also been shown to independently lower CRP and reduce cardiovascular events related to hypertension [30]. In a previous study, patients with COPD included higher proportions of smokers with elevated CRP, leukocytosis, interleukin (IL)-6, and tumor necrosis factor (TNF)- $\alpha$ levels when compared to patients without
COPD [31]. Furthermore, in this study, the mean CRP level declined with longer durations of smoking cessation. After adjusting for covariates to reduce the influence of confounding factors that induce CRP elevation, multivariate logistic regression analysis identified GOLD class, smoking status, and hypertension as the factors significantly associated with high CRP levels, consistent with the results of previous reports [32].

In this study, compared to $\mathrm{PM}_{10}$ exposure levels, the exposure levels of $\mathrm{PM}_{2.5}$ had a greater effect on peripheral blood CRP concentration. This may be due to different degrees of deposition of particulate air pollutants in the lungs, leading to different physiological and pathological changes. Large particles can enter the upper airways, while ultrafine particles can be deposited in the alveoli, translocate from sites in the lung through systemic circulation, and can easily induce systemic inflammation [33]. Inflammation and hypercoagulability are considered to be the potential mechanisms underlying PM-induced adverse cardiovascular events. As indicated by the results of this study, hypertension and coronary heart disease were identified as risk factors for increased CRP levels in patients with AECOPD, consistent with the data reported in the current literature [34].

COPD patients had a higher percentage of cardiovascular-related deaths than those without COPD [35]. With increasing air pollution, the risk of cardiovascular disease is also increasing [36]. Air pollution has been shown to elevate platelet aggregation and coagulation in healthy volunteers [27]. In addition, in patients with stable COPD, a higher D-dimer level was identified as a predictor of higher mortality, and higher levels of thrombin AT-III complex was associated with an increased risk of exacerbations in patients with COPD [37]. However, there is a lack of precise epidemiological data on the 
Table $6 \mathrm{PM}_{2.5}$ levels on the day before hospitalization associated with PT changes in AECOPD patients

\begin{tabular}{|c|c|c|c|c|c|c|}
\hline \multirow[t]{2}{*}{ Variable } & \multicolumn{6}{|c|}{$\mathrm{PM}_{2.5}$ The day before hospitalization } \\
\hline & $<25 \mathrm{mg} / \mathrm{L}$ & $F / t$ & $p$ & $\geq 25 \mathrm{mg} / \mathrm{L}$ & $F / t$ & $p$ \\
\hline \multicolumn{7}{|c|}{ GOLD classes } \\
\hline Moderate & $12.57 \pm 1.62$ & 0.488 & 0.784 & $12.71 \pm 1.10$ & 9.683 & 0.008 \\
\hline Severe & $12.67 \pm 3.37$ & & & $12.05 \pm 2.10$ & & \\
\hline Very severe & $12.50 \pm 1.76$ & & & $11.75 \pm 1.47$ & & \\
\hline \multicolumn{7}{|l|}{ Age years } \\
\hline$<65$ & $12.01 \pm 4.10$ & 1.146 & 0.255 & $11.92 \pm 2.03$ & 0.627 & 0.531 \\
\hline$\geq 65$ & $12.81 \pm 2.23$ & & & $12.09 \pm 1.83$ & & \\
\hline \multicolumn{7}{|l|}{ Sex } \\
\hline Female & $12.36 \pm 1.00$ & 0.406 & 0.686 & $11.77 \pm 1.81$ & 0.924 & 0.357 \\
\hline Male & $12.67 \pm 3.01$ & & & $12.05 \pm 1.88$ & & \\
\hline \multicolumn{7}{|l|}{ BMI (kg/m²) } \\
\hline$<18.5$ & $11.35 \pm 2.43$ & 0.946 & 0.347 & $11.62 \pm 1.09$ & 1.213 & 0.226 \\
\hline$\geq 18.5$ & $12.69 \pm 2.78$ & & & $12.09 \pm 1.97$ & & \\
\hline \multicolumn{7}{|c|}{ Current smoker } \\
\hline Yes & $13.13 \pm 3.70$ & 0.450 & 0.654 & $12.01 \pm 1.91$ & 0.378 & 0.71 \\
\hline No & $12.60 \pm 2.72$ & & & $12.14 \pm 1.79$ & & \\
\hline \multicolumn{7}{|c|}{ Passive smoking } \\
\hline Yes & $12.46 \pm 2.41$ & 0.367 & 0.715 & $12.11 \pm 1.75$ & 0.392 & 0.695 \\
\hline No & $12.69 \pm 2.93$ & & & $12.00 \pm 2.13$ & & \\
\hline \multicolumn{7}{|c|}{ Use of statins } \\
\hline Yes & $13.49 \pm 3.16$ & 1.126 & 0.263 & $12.17 \pm 1.71$ & 0.441 & 0.659 \\
\hline No & $12.49 \pm 2.70$ & & & $12.00 \pm 2.49$ & & \\
\hline \multicolumn{7}{|c|}{ Inhaled corticosteroids } \\
\hline Yes & $12.67 \pm 2.90$ & 0.549 & 0.585 & $12.00 \pm 1.76$ & 0.570 & 0.569 \\
\hline No & $12.18 \pm 1.44$ & & & $12.20 \pm 2.51$ & & \\
\hline \multicolumn{7}{|c|}{ Comorbidities } \\
\hline \multicolumn{7}{|c|}{ Hypertension } \\
\hline Yes & $13.11 \pm 2.13$ & 0.988 & 0.326 & $12.14 \pm 1.40$ & 0.603 & 0.547 \\
\hline No & $12.26 \pm 3.11$ & & & $11.98 \pm 2.10$ & & \\
\hline \multicolumn{7}{|c|}{ Coronary heart disease } \\
\hline Yes & $13.16 \pm 1.82$ & 1.108 & 0.271 & $12.15 \pm 2.31$ & 0.549 & 0.584 \\
\hline No & $12.42 \pm 3.01$ & & & $11.99 \pm 1.74$ & & \\
\hline \multicolumn{7}{|l|}{ Diabetes } \\
\hline Yes & $13.05 \pm 1.51$ & 0.581 & 0.563 & $12.34 \pm 1.38$ & 1.026 & 0.306 \\
\hline No & $12.55 \pm 2.91$ & & & $11.98 \pm 1.96$ & & \\
\hline \multicolumn{7}{|l|}{ Asthma } \\
\hline Yes & $12.84 \pm 1.05$ & 0.243 & 0.809 & $11.64 \pm 1.36$ & 0.949 & 0.344 \\
\hline No & $12.59 \pm 2.88$ & & & $12.07 \pm 1.93$ & & \\
\hline
\end{tabular}

$p$-values are shown for the Kruskal-Wallis test or the Student's t-test

$\mathrm{PM}_{2.5}$, Particulate matter smaller than $2.5 \mu \mathrm{m}$ in diameter; $\mathrm{PM}_{10}$, Particulate matter smaller than $10 \mu \mathrm{m}$ in diameter; BMI, Body Mass Index; GOLD, Global Initiative for Chronic Obstructive Lung Disease

changes in coagulation function induced by air pollution in patients with AECOPD.

$\mathrm{PT}$ is one of the most frequently performed tests to assess global coagulation involving plasma clotting factors I, II, V, and VII [38]. Epidemiological studies have demonstrated that PM exposure shortened PT and increased the plasma level of FIB, and that these hemostatic disturbances were associated with the development of deep vein thrombosis (DVT); moreover, a higher mean PM level in the year before the examination was associated with shortened PT, increasing the risk of DVT [39]. Our study finding indicate that $\mathrm{PM}_{2.5}$ 
Table 7 PM levels on the day before hospitalization associated with CRP, incidence of comorbidities, BMI, smoking status, and administration of drugs stratified by odds ratio and 95\% confidence interval

\begin{tabular}{|c|c|c|c|c|c|c|c|}
\hline \multirow[t]{3}{*}{ Variables } & \multicolumn{2}{|l|}{ CRR } & \multicolumn{2}{|c|}{ Crude } & \multicolumn{2}{|c|}{ Adjusted } & \multirow[t]{3}{*}{$p$ value } \\
\hline & $<10 \mathrm{mg} / \mathrm{L}$ & $\geq 10 \mathrm{mg} / \mathrm{L}$ & OR & $95 \% \mathrm{Cl}$ & OR & $95 \% \mathrm{Cl}$ & \\
\hline & $n=191$ & $n=126$ & & & & & \\
\hline \multicolumn{8}{|l|}{ Age years } \\
\hline$<65$ & 65 (20.50\%) & $36(11.36 \%)$ & 1.29 & $(0.791,2.103)$ & - & - & - \\
\hline$\geq 65$ & 126 (39.75\%) & 90 (28.39\%) & & & & & \\
\hline \multicolumn{8}{|l|}{ Sex } \\
\hline Female & 38 (11.99\%) & $26(8.20 \%)$ & 1.05 & $(0.599,1.831)$ & - & - & - \\
\hline Male & 153 (48.26\%) & $100(31.55 \%)$ & & & & & \\
\hline \multicolumn{8}{|l|}{ BMI } \\
\hline$<18.5 \mathrm{~kg} / \mathrm{m}^{2}$ & $19(5.99 \%)$ & 12 (3.79\%) & 0.95 & $(0.445,2.039)$ & - & - & - \\
\hline$\geq 18.5 \mathrm{~kg} / \mathrm{m}^{2}$ & $172(54.26 \%)$ & $114(35.96 \%)$ & & & & & \\
\hline \multicolumn{8}{|l|}{ GOLD classes } \\
\hline Moderate & 20 (6.31\%) & $11(3.47)$ & 0.82 & $(0.378,1.771)$ & 1.5 & $(1.002,2.236)$ & 0.049 \\
\hline Severe & $126(39.75)$ & $70(22.08 \%)$ & 0.65 & $(0.406,1.023)$ & & & \\
\hline Very severe & 45 (14.20\%) & 45 (14.20\%) & 1.80 & $(1.099,2.955)$ & & & \\
\hline \multicolumn{8}{|l|}{ Current smoker } \\
\hline Yes & 18 (5.68\%) & $24(7.57)$ & 2.26 & $(1.171,4.368)$ & 2.1 & $(1.109,4.361)$ & 0.024 \\
\hline No & 173 (54.57\%) & $102(32.18 \%)$ & & & & & \\
\hline \multicolumn{8}{|l|}{ Passive smoking } \\
\hline Yes & 65 (20.50\%) & 42 (13.25\%) & 0.97 & $(0.602,1.560)$ & - & - & - \\
\hline No & 126 (39.75\%) & 84 (26.50\%) & & & & & \\
\hline \multicolumn{8}{|l|}{ Use of statins } \\
\hline Yes & 38 (11.99\%) & 20 (6.31\%) & 0.76 & $(0.419,1.378)$ & - & - & - \\
\hline No & 153 (48.26\%) & $106(33.44 \%)$ & & & & & \\
\hline \multicolumn{8}{|l|}{ Inhaled corticosteroids } \\
\hline Yes & 163 (51.42\%) & $110(34.70 \%)$ & 0.77 & $(0.401,1.447)$ & - & - & - \\
\hline No & $28(8.83 \%)$ & $16(5.05 \%)$ & & & & & \\
\hline \multicolumn{8}{|l|}{ Comorbidities } \\
\hline Hypertension & $60(18.93 \%)$ & $56(17.67 \%)$ & 1.75 & $(1.096,2.783)$ & 1.65 & $(1.019,2.683)$ & 0.042 \\
\hline Coronary heart disease & $39(12.30 \%)$ & $40(12.62 \%)$ & 1.81 & $(1.084,3.032)$ & 1.63 & $(0.952,2.774)$ & 0.075 \\
\hline Diabetes & 27 (8.52\%) & 19 (5.99\%) & 1.08 & $(0.571,2.036)$ & - & - & - \\
\hline Asthma & $12(3.79 \%)$ & $15(4.73 \%)$ & 2.02 & $(0.910,4.465)$ & - & - & - \\
\hline Bronchiectasis & $3(0.95 \%)$ & $4(1.26 \%)$ & 2.06 & $(0.452,9.340)$ & - & - & - \\
\hline \multicolumn{8}{|l|}{$\mathrm{PM}_{2.5}$} \\
\hline$\geq 25 \mathrm{ug} / \mathrm{m}^{3}$ & $126(39.75 \%)$ & $102(32.18 \%)$ & 2.19 & $(1.283,3.747)$ & 1.91 & $(1.101,3.315)$ & 0.021 \\
\hline$<25 \mathrm{ug} / \mathrm{m}^{3}$ & $65(20.50 \%)$ & $24(7.57 \%)$ & & & & & \\
\hline \multicolumn{8}{|l|}{$\mathrm{PM}_{10}$} \\
\hline$\geq 50 \mathrm{ug} / \mathrm{m}^{3}$ & 94 (29.65\%) & $81(25.56 \%)$ & 1.86 & $(1.170,2.948)$ & - & - & - \\
\hline$<50 \mathrm{ug} / \mathrm{m}^{3}$ & $97(30.60 \%)$ & 45 (14.20\%) & & & & & \\
\hline
\end{tabular}

CRP, C-reactive protein; $\mathrm{PM}_{25}$, Particulate matter smaller than $2.5 \mu \mathrm{m}$ in diameter; $\mathrm{PM}_{10}$, Particulate matter smaller than $10 \mu \mathrm{m}$ in diameter; GOLD, Global Initiative for Chronic Obstructive Lung Disease; BMI, Body Mass Index

Variables found to be statistically significant in the multivariable unconditional logistic regression model. Adjusted for GOLD classes, current smoker, hypertension, coronary heart disease, $\mathrm{PM}_{2.5}$ and $\mathrm{PM}_{10}$

exposure level $\geq 25 \mathrm{mg} / \mathrm{L}$ on the day before hospitalization shortened PT in patients with AECOPD, especially in those with more severe AECOPD. This finding provides a scientific basis for the prevention of blood hypercoagulability in patients with AECOPD following short-term (i.e. on the day before hospitalization) exposure to elevated levels of air pollutants. Our findings also showed that the severe GOLD class and higher 
$\mathrm{PM}_{2.5}$ exposure levels were risk factors for increased CRP levels in patients with AECOPD. CRP may exert direct effects to aggravate endothelial dysfunction and induce augmented procoagulant responses [40]. Thus, patients with AECOPD with severe GOLD class are more sensitive to developing $\mathrm{PM}_{2.5}$ exposure-induced coagulation disorders. This increased sensitivity may be related to the increased CRP concentration in these patients.

PM contains volatile mixtures of numerous heavy metals, organic compounds, and carcinogens that interact with in vivo cellular mechanisms and induce vascular damage, including endothelium inflammation, development of atherosclerosis, lipid peroxidation, alterations in cytokines and acute phase protein levels (such as CRP), and procoagulant responses [41, 42]. The mechanisms by which PM accelerates disease progression in COPD involve changes in the prooxidant-antioxidant balance [43]. Air PM increases the levels of reactive oxygen species (ROS), disrupts cell homeostasis, or activates the redox-sensitive signaling pathway to activate inflammatory cells, pro-inflammatory gene expression, and cytokine production [44]. Oxidative stress markers, measured as thiobarbituric acid reactive substances, were positively correlated with the score of the COPD Modified Medical Research Council scale [29]. PM also reportedly increases ROS production, and PM exposure-induced activation of NOX-4 enzyme production in human aortic endothelial cells leads to the regulation of tissue factor mRNA, resulting in the rapid onset of thrombin generation and fibrin clot formation [45]. In another study, PM exposure induced sustained dosedependent dysfunction of the pulmonary endothelial cell barrier via ROS-induced generation of truncated oxidized phospholipids (Tr-OxPLs) [46].

This study had several limitations. First, only few patients with mild COPD were assessed. Inpatients have a complete medical history and laboratory test results that make them highly suitable for inclusion in a retrospective analysis. However, there were fewer COPD inpatients with mild GOLD class disease or they do not meet the main criteria for the diagnosis of AECOPD. Second, although oxidative stress plays an important role in air pollution-induced airway disease exacerbation, owing to the inherent limitations of retrospective analysis, we were unable to obtain the measures of indicators of oxidative stress in hospitalized patients, which could be addressed in future studies. Third, the composition of PM remarkably varies in presence of a broad range of sources, however, national air quality monitoring stations are used to define exposure status across a large geographical area. The present study did not consider the effects of indoor air quality or domestic fuel types. Fourth, 81 (18\%) patients were excluded due to incomplete data, which could make potential bias due to missing data. Our results, although preliminary, indicated that a high PM exposure level on the day before hospitalization was associated with an increased CRP level and shortened PT in patients with AECOPD. Larger prospective studies, including sequential measurements of clinical biomarkers and more granular air quality data (e.g., at residential location), are therefore required to provide a conclusive, scientific basis for the development of thromboembolic disease in patients with AECOPD with a long-term exposure to high levels of air pollutants.

\section{Conclusions}

Collectively, our findings showed alterations in the prothrombotic state and levels of CRP in AECOPD, which were associated with short-term exposure to ambient air pollution. This study also demonstrated the greater adverse effects of $\mathrm{PM}_{2.5}$ exposure when compared to those of $\mathrm{PM}_{10}$ exposure. AECOPD patients who are subjected to high PM levels should be aware of the risk of shortened PT, especially patients in a severe GOLD class. Considering the limitations of this study, additional prospective studies should be conducted to confirm our findings.

\section{Abbreviations}

BMI: Body mass index; GOLD: Global Initiative for Chronic Obstructive Lung Disease; $\mathrm{PM}_{2.5}$ : Particulate matter smaller than $2.5 \mu \mathrm{m}$ in diameter; TT: Thrombin time; PT: Prothrombin time; FIB: Fibrinogen; APTT: Activated partial thromboplastin time; CRP: C-reactive protein; $\mathrm{PM}_{10}$ : Particulate matter smaller than

$10 \mu \mathrm{m}$ in diameter; DVT: Deep vein thrombosis; ROS: Reactive oxygen species.

\section{Acknowledgements}

The authors thank the Putuo Hospital and its directors for allowing us to carry out the study and access the patients' medical records, to Dr Qingge Chen, for his contribution in the discussion of this study.

\section{Authors' contributions}

$X B W$ and LLT substantially planned and conducted this study, and participated in the data interpretation. LLT, BHW, LL, YY, XHS, and ZHN conducted data management and statistical analysis. SFS critically revised the article. All authors read and approved the final manuscript.

\section{Funding}

This study was financially supported by the Plan of Clinical Specialty Construction in Shanghai Putuo District Health System (Grant No. 2020tszk02) and the National Natural Science Foundation of China (Grant Nos. 81774267 and 82004265).

Availability of data and materials

Data are available from the corresponding author upon reasonable request.

\section{Declarations}

Ethics approval

The study protocol was approved by the Ethics Committee of the Putuo Hospital Affiliated to Shanghai University of Traditional Chinese Medicine (Approval No. PTEC-A-2018-25-1).

Consent for publication

Not applicable. 


\section{Competing interests}

The authors declare no competing interests.

\section{Author details}

${ }^{1}$ Affiliated Hospital of Nanjing University of Chinese Medicine, Nanjing 210029, Jiangsu, China. ${ }^{2}$ Department of Respiratory Medicine, Affiliated Hospital of Nanjing University of Chinese Medicine, Nanjing 210029, Jiangsu, China. ${ }^{3}$ Department of Central Lab, Affiliated Hospital of Nanjing University of Chinese Medicine, Nanjing 210029, Jiangsu, China. ${ }^{4}$ Department of Respiratory Medicine, Putuo Hospital, Shanghai University of Traditional Chinese Medicine, Shanghai 200062, China. ${ }^{5}$ Department of Central Lab, Putuo Hospital, Shanghai University of Traditional Chinese Medicine, Shanghai 200062, China.

\section{Received: 17 May 2021 Accepted: 28 August 2021}

Published online: 18 September 2021

\section{References}

1. Lee MK, Xu CJ, Carnes MU, Nichols CE, Ward JM, consortium B, Kwon SO, Kim SY, Kim WJ, London SJ. Genome-wide DNA methylation and longterm ambient air pollution exposure in Korean adults. Clin Epigenetics. 2019;11(1):37

2. Choi J, Oh JY, Lee YS, Min KH, Hur GY, Lee SY, Kang KH, Shim JJ. Harmful impact of air pollution on severe acute exacerbation of chronic obstructive pulmonary disease: particulate matter is hazardous. Int J Chron Obstruct Pulm Dis. 2018;13:1053-9.

3. Morantes-Caballero JA, Fajardo Rodriguez HA. Effects of air pollution on acute exacerbation of chronic obstructive pulmonary disease: a descriptive retrospective study (pol-AECOPD). Int J Chronic Obstruct Pulm Dis. 2019;14:1549-57.

4. Ni L, Chuang CC, Zuo L. Fine particulate matter in acute exacerbation of COPD. Front Physiol. 2015;6:294.

5. Liu Y, Yan S, Poh K, Liu S, lyioriobhe E, Sterling DA. Impact of air quality guidelines on COPD sufferers. Int J Chronics Obstruct Pulm Dis. 2016;11:839-72

6. UKHACC. Briefing for environment bill in the last parliamentary session. www.ukhealthalliance.org/.

7. Shute JK, Puxeddu E, Calzetta L. Therapeutic use of heparin and derivatives beyond anticoagulation in patients with bronchial asthma or COPD. Curr Opin Pharmacol. 2018;40:39-45.

8. Shi X, Li H. Anticoagulation therapy in patients with chronic obstructive pulmonary disease in the acute exacerbation stage. Exp Ther Med. 2013;5(5):1367-70.

9. Viehmann A, Hertel S, Fuks K, Eisele L, Moebus S, Mohlenkamp S, Nonnemacher $\mathrm{M}$, Jakobs $\mathrm{H}$, Erbel $\mathrm{R}$, Jockel KH, et al. Long-term residential exposure to urban air pollution, and repeated measures of systemic blood markers of inflammation and coagulation. Occup Environ Med. 2015;72(9):656-63.

10. Liu C, Cai J, Qiao L, Wang H, Xu W, Li H, Zhao Z, Chen R, Kan H. The acute effects of fine particulate matter constituents on blood inflammation and coagulation. Environ Sci Technol. 2017;51(14):8128-37.

11. Dong $D, X u X, X u W, X i e J$. The relationship between the actual level of air pollution and residents' concern about air pollution: evidence from Shanghai, China. Int J Environ Res Public Health. 2019;16(23):4784.

12. OMS. Guías de calidad del aire de la OMS relativas al material particulado, el ozono, el dióxido de nitrógeno y el dióxido de azufre (Actualización 2005) [Internet]; 2005. Available from: http://apps.who.int/iris/bitstream/ 10665/69478/1/WHO_SDE_PHE_OEH_06.02_spa.pdf. Accessed 30 Jan 2016.

13. Sun J, Liang M, Shi Z, Shen F, Li J, Huang L, Ge X, Chen Q, Sun Y, Zhang Y, et al. Investigating the PM2.5 mass concentration growth processes during 2013-2016 in Beijing and Shanghai. Chemosphere. 2019;221:452-63.

14. Global Initiative for Chronic Obstructive Lung Disease (GOLD). Global strategy for the diagnosis, management and prevention of COPD. Global Initiative for Chronic Obstructive Lung Disease. 2016.

15. Ridker PM. Clinical application of C-reactive protein for cardiovascular disease detection and prevention. Circulation. 2003;107(3):363-9.

16. Coogan PF, Castro-Webb N, Yu J, O'Connor GT, Palmer JR, Rosenberg L. Active and passive smoking and the incidence of asthma in the Black Women's Health Study. Am J Respir Crit Care Med. 2015;191(2):168-76.
17. Wang W, Ying Y, Wu Q, Zhang H, Ma D, Xiao W. A GIS-based spatial correlation analysis for ambient air pollution and AECOPD hospitalizations in Jinan, China. Respir Med. 2015;109(3):372-8.

18. Lin LY, Chuang HC, Liu IJ, Chen HW, Chuang KJ. Reducing indoor air pollution by air conditioning is associated with improvements in cardiovascular health among the general population. Sci Total Environ. 2013;463-464:176-81.

19. Gao N, Xu W, Ji J, Yang Y, Wang ST, Wang J, Chen X, Meng S, Tian X, Xu KF. Lung function and systemic inflammation associated with short-term air pollution exposure in chronic obstructive pulmonary disease patients in Beijing, China. Environ Health. 2020;19(1):12.

20. Yao Y, Chen X, Chen W, Wang Q, Fan Y, Han Y, Wang T, Wang J, Qiu X, Zheng $M$, et al. Susceptibility of individuals with chronic obstructive pulmonary disease to respiratory inflammation associated with shortterm exposure to ambient air pollution: A panel study in Beijing. Sci Total Environ. 2020;766:142639.

21. Garshick E, Grady ST, Hart JE, Coull BA, Schwartz JD, Laden F, Moy ML, Koutrakis P. Indoor black carbon and biomarkers of systemic inflammation and endothelial activation in COPD patients. Environ Res. 2018;165:358-64.

22. Seaton A, MacNee W, Donaldson K, Godden D. Particulate air pollution and acute health effects. Lancet. 1995;345(8943):176-8.

23. Adar SD, D'Souza J, Mendelsohn-Victor K, Jacobs DR, Cushman M, Sheppard L, Thorne PS, Burke GL, Daviglus ML, Szpiro AA, et al. Markers of inflammation and coagulation after long-term exposure to coarse particulate matter: a cross-sectional analysis from the multi-ethnic study of atherosclerosis. Environ Health Perspect. 2015;123(6):541-8.

24. Marin A, Garcia-Aymerich J, Sauleda J, Belda J, Millares L, Garcia-Nunez M, Serra I, Benet M, Agusti A, Anto JM, et al. Effect of bronchial colonisation on airway and systemic inflammation in stable COPD. COPD. 2012;9(2):121-30.

25. Dahl M, Vestbo J, Lange P, Bojesen SE, Tybjaerg-Hansen A, Nordestgaard BG. C-reactive protein as a predictor of prognosis in chronic obstructive pulmonary disease. Am J Respir Crit Care Med. 2007;175(3):250-5.

26. Liu Q, Gu X, Deng F, Mu L, Baccarelli AA, Guo X, Wu S. Ambient particulate air pollution and circulating C-reactive protein level: A systematic review and meta-analysis. Int J Hyg Environ Health. 2019;222(5):756-64.

27. Rudez G, Janssen NA, Kilinc E, Leebeek FW, Gerlofs-Nijland ME, Spronk $H$ M, ten Cate H, Cassee FR, de Maat MP. Effects of ambient air pollution on hemostasis and inflammation. Environ Health Perspect. 2009;117(6):995-1001.

28. Li Y, Rittenhouse-Olson K, Scheider WL, Mu L. Effect of particulate matter air pollution on C-reactive protein: a review of epidemiologic studies. Rev Environ Health. 2012;27(2-3):133-49.

29. Folchini F, Nonato NL, Feofiloff E, D'Almeida V, Nascimento O, Jardim JR. Association of oxidative stress markers and C-reactive protein with multidimensional indexes in COPD. Chron Respir Dis. 2011;8(2):101-8.

30. Devaraj S, Siegel D, Jialal I. Statin therapy in metabolic syndrome and hypertension post-JUPITER: what is the value of CRP? Curr Atheroscler Rep. 2011;13(1):31-42.

31. Serapinas D, Narbekovas A, Juskevicius J, Sakalauskas R. Systemic inflammation in COPD in relation to smoking status. Multidiscip Respir Med. 2011;6(4):214-9.

32. Lao XQ, Jiang CQ, Zhang WS, Adab P, Lam TH, Cheng KK, Thomas GN. Smoking, smoking cessation and inflammatory markers in older Chinese men: the Guangzhou Biobank Cohort Study. Atherosclerosis. 2009;203(1):304-10.

33. Falcon-Rodriguez Cl, Osornio-Vargas AR, Sada-Ovalle I, Segura-Medina P. Aeroparticles, composition, and lung diseases. Front Immunol. 2016;7:3.

34. Ndrepepa G, Kastrati A, Braun S, Mehilli J, Niemoller K, von Beckerath $\mathrm{N}$, von Beckerath O, Vogt W, Schomig A. N-terminal probrain natriuretic peptide and C-reactive protein in stable coronary heart disease. Am J Med. 2006;119(4):355.e1-355.e8.

35. Malerba M, Nardin M, Radaeli A, Montuschi P, Carpagnano GE, Clini E. The potential role of endothelial dysfunction and platelet activation in the development of thrombotic risk in COPD patients. Expert Rev Hematol. 2017;10(9):821-32.

36. Franklin BA, Brook R, Arden Pope C. Air pollution and cardiovascular disease. Curr Probl Cardiol. 2015;40(5):207-38. 
37. Husebo GR, Gabazza EC, D’Alessandro Gabazza C, Yasuma T, Toda M, Aanerud M, Nielsen R, Bakke PS, Eagan TML. Coagulation markers as predictors for clinical events in COPD. Respirology. 2020;26(4):342-51.

38. Levy JH, Szlam F, Wolberg AS, Winkler A. Clinical use of the activated partial thromboplastin time and prothrombin time for screening: a review of the literature and current guidelines for testing. Clin Lab Med. 2014;34(3):453-77.

39. Baccarelli A, Martinelli I, Zanobetti A, Grillo P, Hou LF, Bertazzi PA, Mannucci PM, Schwartz J. Exposure to particulate air pollution and risk of deep vein thrombosis. Arch Intern Med. 2008;168(9):920-7.

40. Abrams ST, Zhang N, Dart C, Wang SS, Thachil J, Guan Y, Wang G, Toh CH. Human CRP defends against the toxicity of circulating histones. J Immunol. 2013;191(5):2495-502.

41. Li N, He F, Liao B, Zhou Y, Li B, Ran P. Exposure to ambient particulate matter alters the microbial composition and induces immune changes in rat lung. Respir Res. 2017;18(1):143.

42. Wang J, Zhou M, Liu BS, Wu JH, Peng X, Zhang YF, Han SQ, Feng YC, Zhu T. Characterization and source apportionment of size-segregated atmospheric particulate matter collected at ground level and from the urban canopy in Tianjin. Environ Pollut. 2016;219:982-92.
43. Wang J, Li Y, Zhao P, Tian Y, Liu X, He H, Jia R, Oliver BG, Li J. Exposure to air pollution exacerbates inflammation in rats with preexisting COPD. Mediat Inflamm. 2020;2020:4260204.

44. Moller P, Danielsen PH, Karottki DG, Jantzen K, Roursgaard M, Klingberg $\mathrm{H}$, Jensen DM, Christophersen DV, Hemmingsen JG, Cao Y, et al. Oxidative stress and inflammation generated DNA damage by exposure to air pollution particles. Mutat Res Rev Mutat Res. 2014;762:133-66.

45. Snow SJ, Cheng W, Wolberg AS, Carraway MS. Air pollution upregulates endothelial cell procoagulant activity via ultrafine particle-induced oxidant signaling and tissue factor expression. Toxicol Sci. 2014;140(1):83-93.

46. Karki P, Meliton A, Shah A, Tian Y, Ohmura T, Sarich N, Birukova AA, Birukov KG. Role of truncated oxidized phospholipids in acute endothelial barrier dysfunction caused by particulate matter. PLOS ONE. 2018;13(11):e0206251.

\section{Publisher's Note}

Springer Nature remains neutral with regard to jurisdictional claims in published maps and institutional affiliations.
Ready to submit your research? Choose BMC and benefit from:

- fast, convenient online submission

- thorough peer review by experienced researchers in your field

- rapid publication on acceptance

- support for research data, including large and complex data types

- gold Open Access which fosters wider collaboration and increased citations

- maximum visibility for your research: over 100M website views per year

At BMC, research is always in progress.

Learn more biomedcentral.com/submissions 